\title{
Tree Diversity and Stand Structure of Permanent Biodiversity Monitoring Area in Mount Makiling
}

PASTOR L. MALABRIGO, JR.

ORCID No. 0000-0002-4254-751X

plmalabrigo@up.edu.ph

Department of Forest Biological Sciences,

College of Forestry and Natural Resources,

University of the Philippines Los Baños,

Laguna, Philippines

\section{ARTHUR GLENN A. UMALI}

ORCID No. 0000-0001-9289-6649

arthurglennumali@yahoo.com

Department of Forest Biological Sciences,

College of Forestry and Natural Resources,

University of the Philippines Los Baños,

Laguna, Philippines

\section{CRISTINO L. TIBURAN, JR.}

ORCID No. 0000-0002-0863-4089

cltiburan@up.edu.ph

Institute of Renewable Natural Resources,

College of Forestry and Natural Resources,

University of the Philippines Los Baños,

Laguna, Philippines 
NELSON M. PAMPOLINA

ORCID No. 0000-0003-0486-364X

nmpampolina@up.edu.ph

Department of Forest Biological Sciences,

College of Forestry and Natural Resources,

University of the Philippines Los Baños,

Laguna, Philippines

\section{JUANCHO B. BALATIBAT}

ORCID No. 0000-0003-3014-9458

jbbalatibat@up.edu.ph

Department of Forest Biological Sciences, College of Forestry and Natural Resources, University of the Philippines Los Baños, Laguna, Philippines

\section{CRUSTY E. TINIO}

ORCID No. 0000-0002-9836-8772 cetinio@up.edu.ph

Department of Forest Biological Sciences, College of Forestry and Natural Resources, University of the Philippines Los Baños, Laguna, Philippines

\section{WILLIE P. ABASOLO}

ORCID No. 0000-0002-8355-4134 wpabasolo@up.edu.ph

Department of Forest Products and Paper Science, College of Forestry and Natural Resources, University of the Philippines Los Baños, Laguna, Philippines 


\author{
AMELITA C. LUNA \\ ORCID No. 0000-0001-6461-7737 \\ acluna@up.edu.ph \\ Office of the Coordinator for Research Extension and Linkages, \\ College of Forestry and Natural Resources, \\ University of the Philippines Los Baños, \\ Laguna, Philippines \\ JEFERSON C. BONCODIN \\ ORCID No. 0000-0003-3741-420X \\ jcboncodin@up.edu.ph \\ Department of Forest Biological Sciences, \\ College of Forestry and Natural Resources, \\ University of the Philippines Los Baños, \\ Laguna, Philippines
}

\begin{abstract}
Following the international protocol for establishment of permanent plots, a two-hectare permanent biodiversity monitoring area (PBMA) was established inside Makiling Forest Reserve. Results of the intensive 100\% inventory revealed that the PBMA holds tremendous tree diversity. A total of 155 tree species were identified. Of these, 148 are indigenous to the Philippines with 47 endemics (30\% endemism). The most abundant native species in the PBMA is Magabuyo (Celtis luzonica) with 2,287 individuals, followed by Balobo (Diplodiscus paniculatus), Tinaang pantai (Drypetes maquilingensis), and Apanang (Mallotus cumingii). The average diameter for all trees inside the plot is $14.28 \mathrm{~cm}$. More than $90 \%$ of the individual trees fall under the category poles and saplings while large trees account to only $0.6 \%$. Twenty-nine (29) species are listed under either the Philippine Red List (Fernando et al. 2008) or the IUCN Red List of Threatened Species (20154). Noteworthy among the list are the six critically endangered (CR) premium timber species including Makaasim (Syzygium nitidum), Kamagong (Diospyros discolor), Narra (Pterocarpus indicus), Bagtikan (Parashorea malaanonan), Guijo (Shorea guiso), and White lauan (Shorea contorta). The geodatabase that includes an interactive map developed in this study is of critical importance for future research activities in the area.
\end{abstract}


Keywords: Permanent biodiversity monitoring area, Makiling Forest Reserve, endemics, threatened species, geodatabase

\section{INTRODUCTION}

Permanent biodiversity monitoring plots are designated areas to study various life forms in particular ecosystems or habitats that are geographically located and permanently gridded with standard markers. The biodiversity resources thriving in these plots can be monitored space-wised in time to determine variations structurally and functionally. The patterns will be useful in conservation science and decision-making process for sustainable management of biodiversity resources, together with the continuous flow of goods and services from various ecosystems. Further, the establishment of permanent plots will be very significant for monitoring long-term ecological research on biodiversity-functioning in relation to climate change. Moreover, information generated from these monitoring stations provides vital lessons and action plans for policy makers to strategize mechanism concerning food security and climate change adaptation and mitigation.

Mt. Makiling was established as a forest reserve as early as 1910 and the only forest reserve in the country that is ceded for the control and administration to a university. Mt. Makiling Forest Reserve (MFR) serves as a living research and laboratory of the University of the Philippines Los Baños (UPLB). It also serves as a geothermal resource and a key ecotourism site in the Philippines. Being a research and laboratory area, numerous studies have been conducted inside MFR, and it has also been the study area of different international and national programs and projects.

Mt. Makiling Forest Reserve is considered as one of the Philippines' 18 centers of plant diversity (Lapitan et al. 2011). Its flora is composed of a huge number of endemic families, genera, and species. According to Pancho (1983), Mt. Makiling harbors an estimated number of about 2,038 vascular plants. However, many of these species are considered to be threatened to face a high risk of extinction. Thus, the establishment of permanent plots that holds this innumerable number of significant plant species is a vital action for the better management and conservation of these resources. The establishment, development, institutionalization, use and maintenance of a Permanent Biodiversity Monitoring Areas (PBMA) in MFR would not only provide a secured/protected landscape for a number of important organisms but would 
also create a field/laboratory and demonstration areas where quality hands-on learning experience for students and researchers could be conducted.

\section{OBJECTIVES OF THE STUDY}

This research was conducted to establish and maintain a permanent biodiversity monitoring area (PBMA) in Mt. Makiling to serve as a permanent laboratory area for monitoring long-term ecological research on biodiversityfunctioning and forest ecosystem dynamics. Specifically, it aimed to: 1) conduct $100 \%$ tree inventory inside the 2-ha PBMA; 2) determine the ecological status of the different species inside PBMA; 3) analyze the stand structure of the PBMA; and 4) develop geodatabase including an Interactive Map of PBMA for easy referencing and information retrieval.

\section{MATERIALS AND METHODS}

\section{Establishment and GIS-mapping of PBMA}

A 2.0-ha plot was established following the international protocol for the establishment of permanent field plots. There were two phases of the geodatabase development of PBMA. First is the establishment of the PBMA and secondly, is the GIS mapping and development of its geodatabase. The former requires actual ground survey and mapping, gridding and monument marking while the latter phase is more focused on building up information on biodiversity in the area using GIS.

The 2.0-ha plot in Mt. Makiling Forest Reserve (MFR) measures $100 \mathrm{~m} \mathrm{x}$ $200 \mathrm{~m}$ following a bearing of $\mathrm{N} 55^{\circ} \mathrm{E}$ and $\mathrm{N} 35^{\circ} \mathrm{W}$, respectively. The tying point of the PBMA is located along this UTM coordinates $-1,563,000$ Northing and 307,723 Easting. The entire plot was then divided into $20010 \mathrm{~m} \times 10 \mathrm{~m}$ grids for easy referencing and more systematic sampling. Monument markers or mojons were driven in every corner and center of each grid. Each mojon was painted with bright color for easy reference. These corners were later geocoded for easy identification in the field and as future reference for efficient encoding of data.

In GIS, there are three types of Data Base Management Systems (DBMS) that are commonly used depending on the way the data are stored and manipulated. These are relational (RDBMS), object (ODBMS), and object-relational (ORDBMS). For this particular study, the RDBMS was applied. A relational database is mainly comprised of a set of tables, each a two- dimensional list (array) 
of records containing attributes about the objects under study. Furthermore, it has proven to be remarkably more flexible and useful in several applications as compared to the other two types of DBMS.

\section{Tree Inventory}

Floristic taxa, composition, and structure were determined from the gridded and geo-based permanent biodiversity monitoring plot. 100\% tree inventory was used for the whole 2-hectare plot. Trees that are $\geq 1 \mathrm{~cm}$ in diameter were tagged, measured and recorded. Different attributes such as diameter at breast height (dbh), merchantable height $(\mathrm{MH})$ and total height $(\mathrm{TH})$ were taken from each tree using standard instruments. To plot the location of each tree on a map, distance and bearing of each tree from the center of each $10 \mathrm{~m} \times 10 \mathrm{~m}$ plot were also taken and recorded using meter tape and compass (Figure 1).

Voucher specimens were also collected for identification, authentication, and herbarium collection. Each specimen was tagged using proper coding prior to storage. Floral identification followed a phylogenetic system of classification. All activities were photo-documented, and floristic data were processed and stored in GIS database for interpretation, analysis, and management purposes.

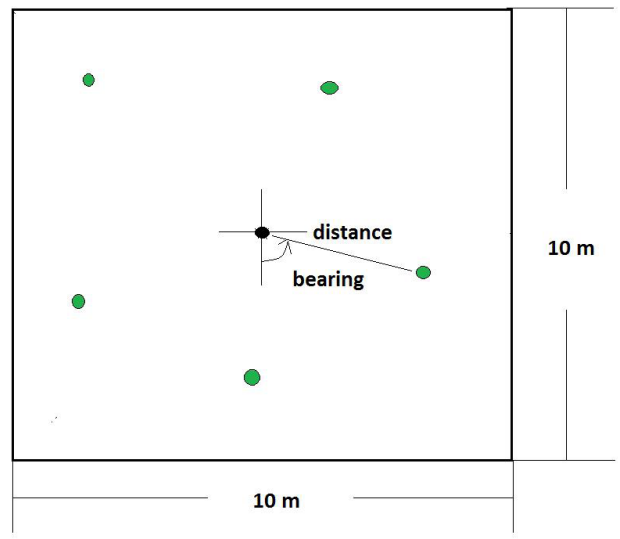

Figure 1. Marking the Position of a Tree Using Distance and Bearing from the Center of the Grid. 

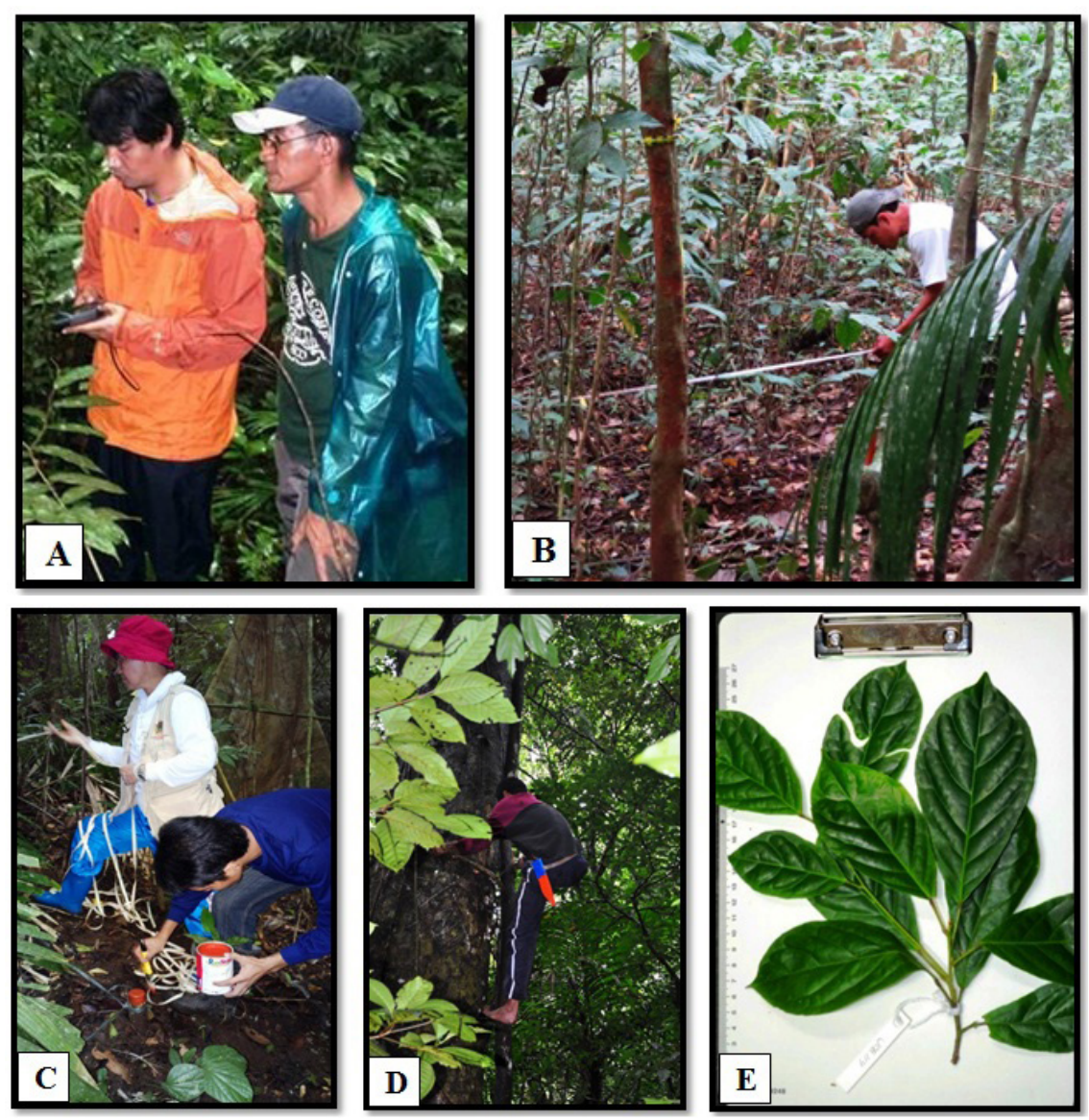

Plate 1. Establishment of Permanent Plot and Collection of Specimens: A) Establishment of benchmark's coordinates; B) Establishment of $10 \mathrm{~m} \times 10 \mathrm{~m}$ grids; C) Painting/marking of mojons of every corner and center of $10 \mathrm{~m} \times 10 \mathrm{~m}$ grid; D) Climber collecting leaf samples as voucher specimens; and E) Properly coded voucher specimen. 


\section{RESULTS AND DISCUSSION}

\section{Tree Diversity}

A total of 155 tree species belonging to 103 genera and 55 families were found present in the permanent plot. Of the 155 species identified, 148 are found to be indigenous (native) to the Philippines of which 47 are endemic or exclusively found in the country. There are six exotic tree species recorded inside the permanent plot. These include kape (Coffea Arabica), bigleaf mahogany (Sweitenia macrophylla), African tulip (Sphatodea campanulata), Malatanglin (Adenanthera pavonina), and Talampunay (Solanum verbascifolium). The genera with the most number of species are Ficus (with nine species), followed by Syzygium (6), Garcinia and Palaquium (5 each) and Canarium (4).

The most abundant species is Magabuyo (Celtis luzonica) with 2,287 (about $26 \%$ of the total) individuals, followed by Kape (Coffea arabica), Balobo (Diplodiscu spaniculatus), Tinaang pantai (Drypetes maquilingensis), and Apanang (Mallotus cumingii). Nine of the ten most abundant species are indigenous species of which two are Philippine endemics (Table 1).

Table 1. Ten Most Abundant Species in the Permanent Plot

\begin{tabular}{|l|l|c|c|}
\hline \multicolumn{1}{|c|}{ Common Name } & \multicolumn{1}{|c|}{ Scientific name } & Abundance & Endemism \\
\hline 1. Magabuyo & Celtis luzonica Warb. & 2287 & $\mathrm{PE}$ \\
\hline 2. Kape & Coffea arabica L. & 747 & $\mathrm{Ex}$ \\
\hline 3. Balobo & Diplodiscus paniculatus Turez. & 512 & $\mathrm{PE}$ \\
\hline 4. Tinaangpantai & Drypetes maquilingensis (Merr.) Pax \& K. Hoffm. & 495 & $\mathrm{NE}$ \\
\hline 5. Apanang & Mallotus cumingii Muell.-Arg. & 454 & $\mathrm{NE}$ \\
\hline 6. Malasaging & Aglaia edulis (Roxb.) Wall. & 336 & $\mathrm{NE}$ \\
\hline 7. Malatapai & Alangium javanicum (Blume) Wangerin & 298 & $\mathrm{NE}$ \\
\hline 8. Katong matsing & $\begin{array}{l}\text { Chisocheton pentandrus (Blanco) Merr. subsp. } \\
\text { pentandrus }\end{array}$ & 297 & $\mathrm{NE}$ \\
\hline 9. Bagtikan & Parashorea malaanonan (Blanco) Merr. & 219 & $\mathrm{NE}$ \\
\hline 10. Tamayuan & Strombosia philippinensis (Baill.) Rolfe & 214 & $\mathrm{NE}$ \\
\hline
\end{tabular}

PE - Philippine endemic; NE - Native but non-endemic; Ex - Exotic

\section{Stand Structure}

A total of 8,806 tree individuals with a diameter at breast height of $1 \mathrm{~cm}$ or more were recorded from the 2-ha plot. This accounts to a plot density of 4,403 trees ha ${ }^{-1}$, which is about 44 trees for every $10 \mathrm{~m} \times 10 \mathrm{~m}$ grid. The computed density is relatively lower as compared to the density of the 16-ha permanent forest plot in Palanan, Isabela at 4,999 trees ha ${ }^{-1}$ (Co et al. 2006). This is understandable since Palanan, which is part of Northern Sierra Madre Mountain Ranges, is an old growth forest while Mt. Makiling is a secondary forest. 
The average diameter of all trees inside the plot is only $14.28 \mathrm{~cm}$. Moreover, there is a big discrepancy in the proportion of the different diameter classes of the trees. More than $90 \%$ of the individual trees fall under the category poles and saplings while the large trees account for only $0.6 \%$ (Table 2). This bias can be attributed to the relatively young forest of Mt. Makiling, which underwent a series of logging operations in the past. The species with the biggest average diameter are Igyo (Dysoxylum gaudichaudianum), Banilad (Sterculia comosa), Bangulo (Litsea garciae), and a species of Saurauia.

Spatial distribution of the inventoried trees was plotted (Figure 2) for easy referencing and future monitoring. More importantly, an interactive map was produced using ArcGIS. Aside from the position of the trees, all information generated for each tree individuals (name, scientific name, family name, dbh, $\mathrm{mh}$, th, etc.) can be viewed by just pointing the cursor to the individual circle on the map (Figure 3). The interactive map was stored and saved in a shapefile (.shp) format. This shapefile will serve as the geodatabase of trees in PBMA-MFR that can be opened using any GIS software.

Table 2. Number of Individuals per Diameter Class

\begin{tabular}{|l|c|c|}
\hline \multicolumn{1}{|c|}{ Diameter Class } & Diameter Range & Number of Individuals \\
\hline Poles and saplings & $<10 \mathrm{~cm}$ & 7,958 \\
\hline Small trees & $10 \mathrm{~cm}$ to $<30 \mathrm{~cm}$ & 591 \\
\hline Medium-size trees & $30 \mathrm{~cm}$ to $<60 \mathrm{~cm}$ & 202 \\
\hline Large trees & $>60 \mathrm{~cm}$ & 55 \\
\hline
\end{tabular}

\section{Ecologically Important Species}

Endemic Species. The geographical distribution of plant species has been very useful for assessing biodiversity values of regions, countries, and islands. Species confined to a particular site should be given particular conservation management strategies, as they are more vulnerable to disturbance due to their narrow range. However, categorizing species as endemic is very much dependent on the availability of recent revisions, nomenclatural changes, and new evidence from various disciplines used in systematics, among others. There are at least 47 Philippine endemics encountered in the study area (Table 3). These account to more than $30 \%$ endemism. This very much conforms to the recently suggested country endemism for Philippine flowering plants at around 25-30\%.

Threatened Species. Twenty-nine (29) species recorded from the area are listed under either the Philippine Red List (DAO 2007-01) or the IUCN Red List of Threatened Species (2012.2). Noteworthy among the list are the six critically 
endangered (CR) premium timber species including Makaasim, Kamagong, Narra, Bagtikan, Guijo, and White lauan (Table 4).

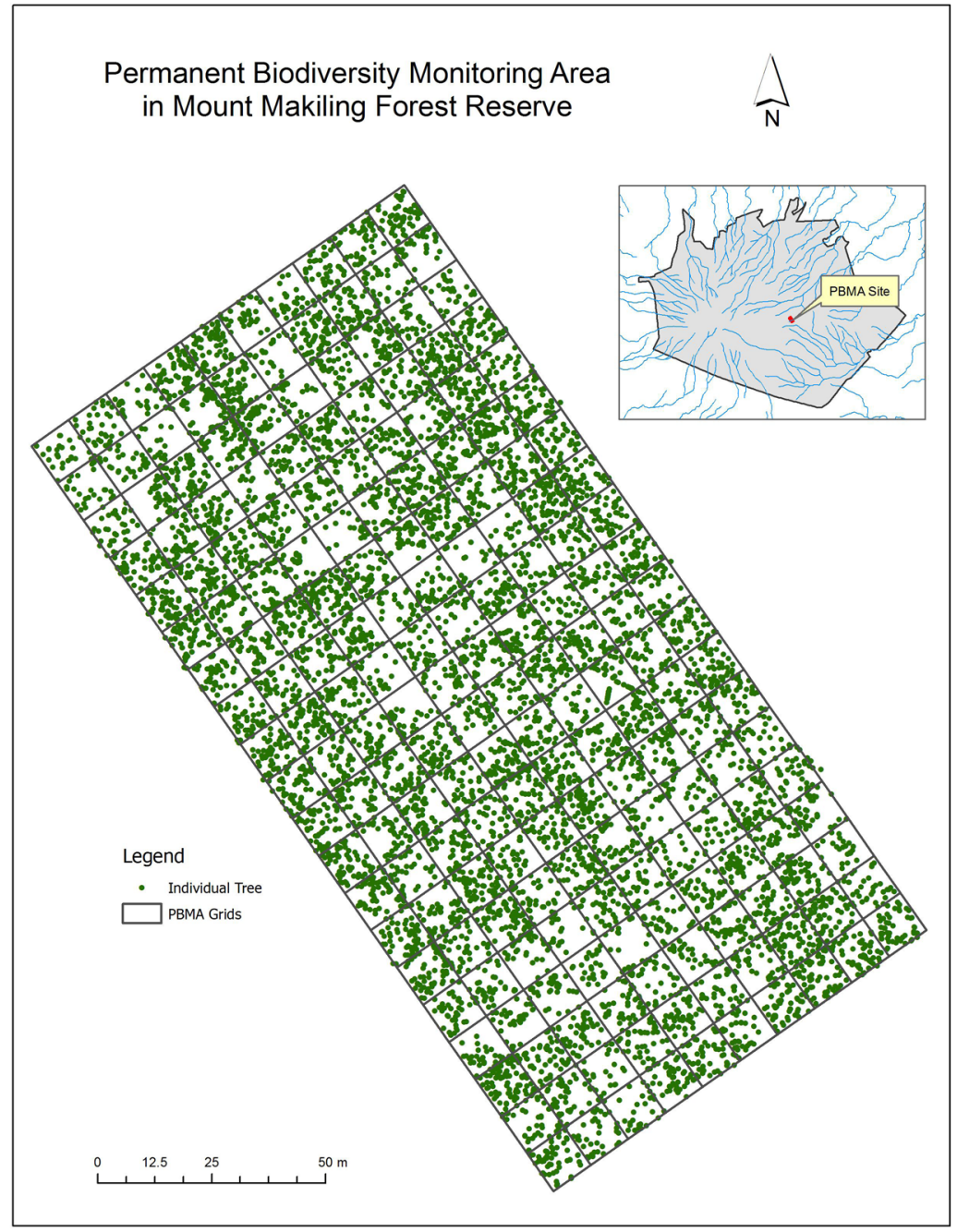

Figure 2. Spatial Distribution of Trees inside the PBMA in Mt. Makiling Forest Reserve. 


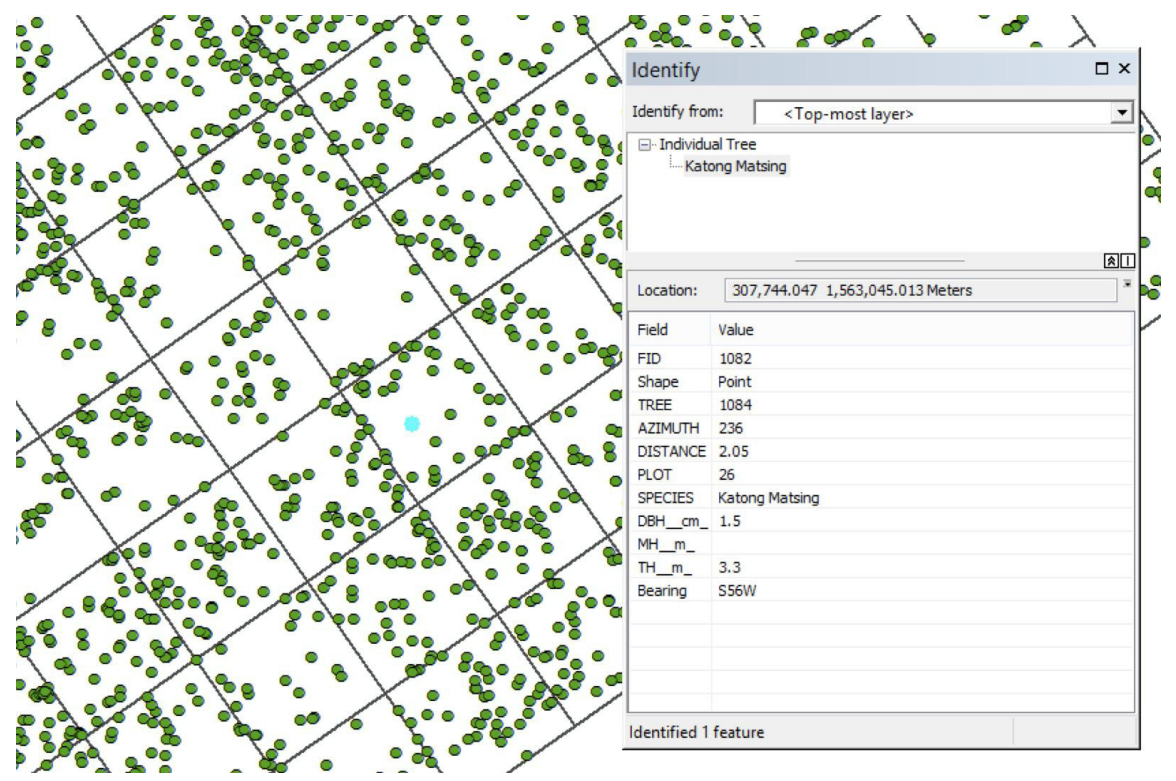

Figure 3. The Interactive Map for PBMA-MFR Displaying the Information for a Chosen Tree. 
Table 3. List of Endemic Species Recorded in the Permanent Plot

\begin{tabular}{|c|c|c|}
\hline Common Name & Scientific name & Family name \\
\hline 1. Tanglin & Adenanthera intermedia Merr. & FABACEAE \\
\hline 2. Tagpo & Ardisia squamolosa Elmer & PRIMULACEAE \\
\hline 3. Anubing & Artocarpus blancoi (Elmer) Merr. & MORACEAE \\
\hline 4. Kalulot & Artocarpus rubrovenius Warb. & MORACEAE \\
\hline 5. Tuai & Bischofia javanica Blume & PHYLLANTHACEAE \\
\hline 6. Piling liitan & Canarium luzonicum Blume (A. Gray) & BURSERACEAE \\
\hline 7. Puni & Canthium megacarum (Merr.) Merr. & RUBIACEAE \\
\hline 8. Magabuyo & Celtis luzonica Warb. & CANNABACEAE \\
\hline 9. Malalipa & Claoxylon albicans (Blanco) Merr. & EUPHORBIACEAE \\
\hline 10. Karaskas & Cryptocarya acuminate Merr. & LAURACEAE \\
\hline 11. Paang dalaga & Cryptocarya pacifica Elmer & LAURACEAE \\
\hline 12. Katmon & Dillenia philippinensis Rolfe & DILLENIACEAE \\
\hline 13. Kamagong & Diospyros blancoi A. DC. & EBENACEAE \\
\hline 14. Balobo & Diplodiscu spaniculatus Turez & MALVACEAE \\
\hline 15. Kalomala & Elaeocarpus calomala (Blanco) Merr. & ELAEOCARPACEAE \\
\hline 16. Balete & Ficus balete Merr. & MORACEAE \\
\hline 17. Pakiling & Ficus odorata (Blanco) Merr. & MORACEAE \\
\hline 18. Binukaw & Garcinia binucao (Blanco) Choisy & CLUSIACEAE \\
\hline 19. Tagkon & Garcinia macgregorii Merr & CLUSIACEAE \\
\hline 20. Kamandiis & Garcinia rubra Merr & CLUSIACEAE \\
\hline 21. Malabagna & Glochidion phyllanthoides Merr. & PHYLLANTHACEAE \\
\hline 22. Mabunot & Gomphandra luzoniensis (Merr.) Merr. & STEMUNORACEAE \\
\hline 23. Bigus & Goniothalamus elmeri Merr. & ANNONACEAE \\
\hline 24. Anuping & $\begin{array}{l}\text { Gymnacranthera farquhariana (Hook.f. \& } \\
\text { Thomson) var paniculata (A.DC.) R.T. } \\
\text { Schouten }\end{array}$ & MYRISTICACEAE \\
\hline 25. Anolang & Haplosticanthus lanceolatus (Vidal) Heusden & ANNONACEAE \\
\hline 26. Mayanman & Lxora longistipula Merr. & RUBIACEAE \\
\hline 27. Mali-mali & Leea guineensis G. Don & LEEACEAE \\
\hline 28. Kaliantan & Leea philippinensis Merr. & LEEACEAE \\
\hline 29. Bangulo & Litsea garciae Vidal & LAURACEAE \\
\hline 30. Hamindang & Macaranga bicolor Muell-Arg & EUPHORBIACEAE \\
\hline 31. Takip asin & Macaranga grandifolia (Blanco) Merr. & EUPHORBIACEAE \\
\hline 32. Matang araw & Melicope triphylla (Lam. Merr) & RUTACEAE \\
\hline 33. Duguan & Myristica philippinensis Lam. & MYRISTICACEAE \\
\hline 34. Tagotoi & Palaquium foxwortyi Merr. & SAPOTACEAE \\
\hline 35. Nato & Palaquium luzoniense (F.Vill) Vidal & SAPOTACEAE \\
\hline 36. Malak-malak bundok & Palaquium montamum Elmer & SAPOTACEAE \\
\hline 37. Malak-malak & Palaquium philippinense (Perr.) C.B. Rob. & SAPOTACEAE \\
\hline 38. Lamog & Planchonia spectabilis Merr. & LECYTHIDACEAE \\
\hline 39. Saurauia & Saurauia denticulate $\mathrm{C}$ Robinson & ACTINIDIACEAE \\
\hline \begin{tabular}{|l|}
40. Kolalabang \\
\end{tabular} & Saurauia latibractea Choisy & ACTINIDIACEAE \\
\hline 41. Saurauia & Saurauia luzoniensis Merr. & ACTINIDIACEAE \\
\hline 42. White lauan & Shorea contorta Vidal & DIPTEROCARPACEAE \\
\hline 43. Kalogkog & Syzygium calcicolum (Merr.) Merr. & MYRTACEAE \\
\hline 44. Kalubkob & Syzygium calubcob (C.B. Rob.) Merr. & MYRTACEAE \\
\hline 45. Malahagnit & Syzygium everettii (C Robinson) Merr. & MYRTACEAE \\
\hline 46. Lipote & Syzygium polycephaloides (C Robinson) Merr. & MYRTACEAE \\
\hline 47. Panglomboien & Syzygium simile (Merr.) Merr. & MYRTACEAE \\
\hline
\end{tabular}


Table 4. List of Threatened Species Recorded in the Permanent Plot

\begin{tabular}{|c|c|c|c|c|}
\hline \multirow[b]{2}{*}{ Species } & \multirow[b]{2}{*}{ Scientific Name } & \multirow[b]{2}{*}{ Family Name } & \multicolumn{2}{|c|}{ Conservation Status } \\
\hline & & & $\begin{array}{l}\text { Fernando } \\
\text { et al. } 2008 \\
\end{array}$ & $\begin{array}{l}\text { IUCN } \\
2015-4 \\
\end{array}$ \\
\hline 1. Makaasim & Syzygium nitidum Benth & Myrtaceae & $\mathrm{CR}$ & \\
\hline 2. Kamagong & Diospyros blancoi A. DC. & Ebenaceae & $\mathrm{CR}$ & $\mathrm{VU}$ \\
\hline 3. Narra & Pterocarpus indicus Wild. & Fabaceae & $\mathrm{CR}$ & VU \\
\hline 4. Bagtikan & $\begin{array}{l}\text { Parashorea malaanonan } \\
\text { (Blanco) Merr. }\end{array}$ & Dipterocarpaceae & & $\mathrm{CR}$ \\
\hline 5. Guijo & $\begin{array}{l}\text { Shorea guiso (Blanco) } \\
\text { Blume }\end{array}$ & Dipterocarpaceae & & CR \\
\hline 6. White Lauan & Shorea contorta Vidal & Dipterocarpaceae & $\mathrm{VU}$ & CR \\
\hline 7. Kubili & $\begin{array}{l}\text { Cubilia cubili (Blanco) } \\
\text { Adelb. }\end{array}$ & Sapindaceae & EN & \\
\hline 8. Anang & Diospyros pyrrhocarpa Miq & Ebenaceae & EN & EN \\
\hline 9. Alupag & $\begin{array}{l}\text { Litchi chinensis Sonn subsp. } \\
\text { philippinensis (Radlk.) } \\
\text { Leenh. }\end{array}$ & Sapindaceae & EN & EN \\
\hline 10. Lamio & $\begin{array}{l}\begin{array}{l}\text { Dracontomelon edule } \\
\text { (Blanco) Merr. }\end{array} \\
\end{array}$ & Anacardiaceae & VU & \\
\hline 11. Malasaging & Aglaia edulis (Roxb.) Wall. & Meliaceae & VU & \\
\hline 12. Bayanti & $\begin{array}{l}\text { Aglaia rimosa (Blanco) } \\
\text { Merr. }\end{array}$ & Meliaceae & VU & \\
\hline 13. Kalulot & $\begin{array}{l}\text { Artocarpus rubrovenius } \\
\text { Warb }\end{array}$ & Moraceae & VU & \\
\hline 14. Malatapai & Alangium longiflorum Merr & Comaceae & VU & VU \\
\hline 15. Kangko & $\begin{array}{l}\text { Aphanamixis polystachya } \\
\text { (Wall.) R.N. Parker } \\
\end{array}$ & Meliaceae & $\mathrm{VU}$ & VU \\
\hline 16. Nato & $\begin{array}{l}\text { Palaquium luzoniense } \\
\text { (F.Vill.) Vidal } \\
\end{array}$ & Sapotaceae & $\mathrm{VU}$ & $\mathrm{VU}$ \\
\hline 17. Malakmalak & $\begin{array}{l}\text { Palaquium philippinense } \\
\text { (Perr.) C.B. Rob. }\end{array}$ & Sapotaceae & vU & VU \\
\hline 18. Piling liitan & $\begin{array}{l}\text { Canarium luzonicum } \\
\text { (Blume) A. Gray }\end{array}$ & Burseraceae & & vU \\
\hline 19. Magabuyo & Celtis luzonica Warb & Cannabaceae & & $\mathrm{vU}$ \\
\hline 20. Katmon & Dillenia philippinensis Rolfe & Dilleniaceae & & $\mathrm{vU}$ \\
\hline 21. Kalomala & $\begin{array}{l}\text { Elaeocarpus calomala } \\
\text { (Blanco) Merr. }\end{array}$ & Elaeocarpaceae & & vU \\
\hline 22. Hamindang & $\begin{array}{l}\text { Macaranga bicolor (Muell- } \\
\text { Arg.) }\end{array}$ & Euphorbiaceae & & vU \\
\hline 23. TakipAsin & $\begin{array}{l}\text { Macaranga grandifolia } \\
\text { (Blanco) Merr. }\end{array}$ & Euphorbiaceae & & VU \\
\hline 24. Tanglin & $\begin{array}{l}\text { Adenanthera intermedia } \\
\text { Merr. }\end{array}$ & Fabaceae & & VU \\
\hline 25. Balobo & $\begin{array}{l}\text { Diplodiscus paniculatus } \\
\text { Turez }\end{array}$ & Malvaceae & & VU \\
\hline 26. Antipolo & $\begin{array}{l}\text { Artocarpus blancoi (Elmer) } \\
\text { Merr. }\end{array}$ & Moraceae & & VU \\
\hline 27. Duguan & $\begin{array}{l}\text { Myristica philippinensis } \\
\text { Lam. }\end{array}$ & Myristicaceae & & VU \\
\hline 28. Tagpo & Ardisia squamolosa Elmer & Myrsinaceae & & $\mathrm{VU}$ \\
\hline 29. Balakat & $\begin{array}{l}\text { Ziziphus talanai (Blanco) } \\
\text { Merr. }\end{array}$ & Rhamnaceae & & VU \\
\hline
\end{tabular}




\section{CONCLUSIONS}

Results of the intensive study revealed that the permanent biodiversity monitoring area in Makiling Forest Reserve holds tremendous tree diversity. It also showed very high species endemism and harbored a significant number of ecologically threatened trees. The geodatabase developed in this research should serve as the baseline information for the PBMA, which is of critical importance for the future research activities in the area. The established PBMA could be a principal venue for current and planned conservation efforts for the Makiling Forest Reserve. The information on the ecological status of the biodiversity in PBMA should be disseminated to advocate conservation.

\section{LITERATURE CITED}

Co LJ, La Frankie JV, Lagunzad DA, Passion KAC, Consunji HT, Bartolome NA, Yap SL, Molina JE, Tongco MDC, Ferreras UF, Davies SJ, Ashton PS. 2006. Forest Trees of Palanan, Philippines: A Study in Population Ecology. Center for Tropical Forest Sciences.

Fernando ES, Co LL, Lagunzad DA, Gruezo WS, Barcelona JF, Madulid DA, Baja-Lapis A,Texon GI, Manila AC, Zamora PM. 2008. Threatened plants of the Philippines: a preliminary assessment. Asia Life Sciences, Supplement 3: 1-52.

Lapitan PG, Fernando ES, Suh MH, Fuentes RU, Shin YK, Pampolina NM, Castillo ML, Cereno RP, Lee SH, Choi TB, Lee DK. 2010. Biodiversity and Natural Resources Conservation in Protected Areas of Korea and the Philippines. Gen Book Bubl. Corp. Korea. pp. 248.

Pancho JV. 1983. Vascular Flora of Makiling and Vicinity (Luzon: Philippines). Part 1. Nee Mercury Printing Press, Quezon City.

The IUCN Red List of Threatened Species. Version 2015-4. <www.iucnredlist.org>. Downloaded on 06 March 2016. 